\title{
Isolation and characterization of a novel acidophilic zero-valent sulfur- and
} ferric iron-respiring Firmicute

Holanda, Roseanne; Johnson, D. Barrie

\section{Research in Microbiology}

DOI:

10.1016/j.resmic.2020.07.003

Published: 18/08/2020

Peer reviewed version

Cyswllt i'r cyhoeddiad / Link to publication

Dyfyniad o'r fersiwn a gyhoeddwyd / Citation for published version (APA):

Holanda, R., \& Johnson, D. B. (2020). Isolation and characterization of a novel acidophilic zerovalent sulfur- and ferric iron-respiring Firmicute. Research in Microbiology, 171(7), 215-221. https://doi.org/10.1016/j.resmic.2020.07.003

\footnotetext{
Hawliau Cyffredinol / General rights

Copyright and moral rights for the publications made accessible in the public portal are retained by the authors and/or other copyright owners and it is a condition of accessing publications that users recognise and abide by the legal requirements associated with these rights.

- Users may download and print one copy of any publication from the public portal for the purpose of private study or research.

- You may not further distribute the material or use it for any profit-making activity or commercial gain

- You may freely distribute the URL identifying the publication in the public portal?
}

Take down policy

If you believe that this document breaches copyright please contact us providing details, and we will remove access to the work immediately and investigate your claim. 


\section{Journal Pre-proof}

Isolation and characterization of a novel acidophilic zero-valent sulfur- and ferric ironrespiring Firmicute

Roseanne Holanda, D. Barrie Johnson

PII:

S0923-2508(20)30077-2

DOI: $\quad$ https://doi.org/10.1016/j.resmic.2020.07.003 Reference:

RESMIC 3774

To appear in: Research in Microbiology

Received Date: 9 April 2020

Revised Date: 17 June 2020

Accepted Date: 17 July 2020

Please cite this article as: R. Holanda, D.B. Johnson, Isolation and characterization of a novel acidophilic zero-valent sulfur- and ferric iron-respiring Firmicute, Research in Microbiologoy, https://doi.org/10.1016/ j.resmic.2020.07.003.

This is a PDF file of an article that has undergone enhancements after acceptance, such as the addition of a cover page and metadata, and formatting for readability, but it is not yet the definitive version of record. This version will undergo additional copyediting, typesetting and review before it is published in its final form, but we are providing this version to give early visibility of the article. Please note that, during the production process, errors may be discovered which could affect the content, and all legal disclaimers that apply to the journal pertain.

(C) 2020 Institut Pasteur. Published by Elsevier Masson SAS. All rights reserved. 
School of Natural Sciences, Bangor University, UK

Present address: SENAI Innovation Institute for Mineral Technologies, Nation I Service for Industrial Training, Belém/PA, 66035-405, Brazil.

rosebarata@gmail.com (correspondence and repriis)

6

$7 \S$

\section{sulfur- and ferric iron-respiring Firmicute.}

\author{
Roseanne Holanda§*, D. Barrie Johnson
}
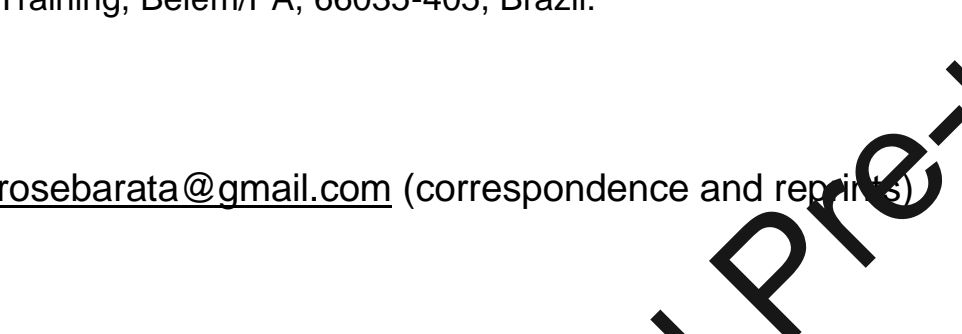

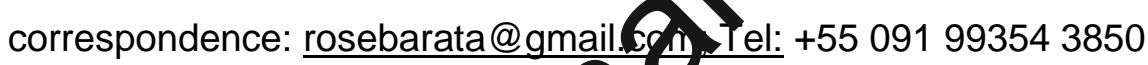

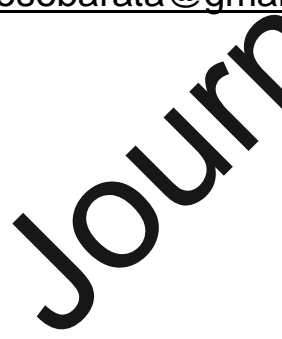

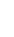

Isolation and characterization of a novel acidophilic zero-valent 
Abstract:

A novel, obligately anaerobic, acidophilic bacterium (strain I2511), isolated from sediment in an abandoned copper mine, was shown to couple the oxidation of organic electron donors to the reduction of both zero-valent sulfur and ferric iron in acidic media. The isolate was an obligate heterotroph that used a variety of organic compounds as electron donors and required yeast extract for growth. Alternative electron acceptors (sulfate, tetrathionate, thiosulfate and nitrate) were not used by the novel isolate. The strain grew as motile, endospore-forming rods, and was mesophilic and moderately acidophilic, with a growth rate of $0.01 \mathrm{~h}^{-1}$ at optimum $\mathrm{pH}(3.7)$ and temperature $\left(35^{\circ} \mathrm{C}\right)$. Analysion ts $16 \mathrm{~S}$ rRNA gene sequence placed strain I2511 within the phylum Firmicutes, dist ntly related to validated species. Phylogenetic analysis and physiological traits indicat the novel strain represents a species of a candidate novel genus. Strain I2511 inclded in a microbial consortium in a low pH "hybrid" sulfidogenic bioreactor degigne to remove chalcophilic metals from metalcontaminated liquors and was presen in $>5 \%$ relative abundance when bioreactor was operated at $\mathrm{pH} \sim 2$ 2.0. Results indicate the the novel isolate could be applied in biotechnologies to treat acidic and neutral $\mathrm{pH}$, mes-rich effluents.

Keywords: Acidophile, Iron reduction, Firmicutes, Obligate anaerobe, Sulfidogenesis, Sulfur reduction

\section{Introduction}

Elemental (zero-valent) sulfur (ZVS) and several sulfur oxyanions can be used as terminal electron acceptors by some prokaryotes, generating hydrogen sulfide. While there are a number of reports describing microbially-catalyzed sulfidogenesis in very acidic natural 
and engineered eco-systems (reviewed in [1]), there have been relatively few reports of pure cultures of bacteria that are capable of generating $\mathrm{H}_{2} \mathrm{~S}$ at extremely low $\mathrm{pH}(<3)$. Thermodesulfobium narugense, isolated from a hot spring in Japan, was the first acidtolerant sulfate-reducing bacterium to be validated [2]; it grows between $\mathrm{pH} 4$ and 6.5 and is a moderate thermophile. Desulfosporosinus (D.) acidiphilus and Desulfosporosinus acididurans are moderately acidophilic sulfate-reducing bacteria (aSRB) that are able to grow at lower $\mathrm{pH}$ (3.6 and above) and can also reduce ZVS [3 - 5]. D. acididurans was reported to represent $6 \%$ of the bacterial population in a sulfidogenic bioreactor maintained at $\mathrm{pH} 2.4$, which was dominated by currently non-validated SRB [6]. A novel Deltaproteobacteria, Desulfurella (Ds.) amilsii, was shown to reduce ZVS at low $\mathrm{pH}$, growing between $\mathrm{pH} 3$ and 7 and optimally at $\mathrm{pH}$ 6 - 6.5 [7]. More recently, the aSRB Thermodesulfobium acidiphilum [8] and Thermodesulfobium sp. strain 3baa [9] have been described as thermophiles which can grow at $\mathrm{pH}$ range of $3.7-6.5$ and $2.6-6.6$, respectively. Currently, there are no reports of ZVSreducing bacteria that grow optimally at $\mathrm{pH}<4$. However, dissimilatory reduction of ZVS at extremely low $\mathrm{pH}$ has been reported for some, mostly hyperthermophilic, archaea, such as Acidianus spp., Stygiolobus azoricus and Sulfurisphaera ohwakuensis. Species of the genus Acidianus (e.g. A. brierleyi, A. infernus, A. ambivalens and A. sulfidivorans), isolated from solfatara environments and acidic thermal springs, are able to grow at $\mathrm{pH}$ as low as 1 , and the minimum growth $\mathrm{pH}$ reported for $A$. sulfidivorans is 0.35 [10].

Many early attempts to isolate sulfidogens in low $\mathrm{pH}$ were unsuccessful because organic acids (e.g. lactate) were used as the main carbon/energy source in enrichment cultures [1]. At $\mathrm{pH}$ below their $\mathrm{p} K_{\mathrm{a}}$ values, organic acids exist mainly in non-dissociated forms. These tend to be lipophilic, and can diffuse into the cells lowering intracellular $\mathrm{pH}$, ultimately causing cell death. Non-ionic substrates such as glycerol, hydrogen and methanol are more suitable electron donors for sulfidogenesis at low $\mathrm{pH}[5,6]$. Another challenge with cultivating sulfidogens in acidic media, also related to the toxicity of organic acids, is that some species are known to be "incomplete substrate oxidizers," and produce and excrete small molecular 
weight organic acids when metabolizing larger molecular weight substrates, again inducing toxicity (e.g. D. acididurans produces acetic acid in stoichiometric equivalents to glycerol oxidized)

Depending on $\mathrm{pH}$, hydrogen sulfide can react with chalcophilic metals, such as copper and zinc, precipitating them as sulfide phases. This is the pringlpehind sulfidogenic bioreactors, which have been widely studied to remove and re over metals from mineimpacted effluents $[6,11]$. Industrial-scale bioreactors curent used for this purpose utilize species of neutrophilic sulfidogens that tend to be high sensitive to both acidity and soluble transition metals that have to be shielded from difect contact with contaminated mine waters [12].

The present study reports 12 characteristics of a novel obligately anaerobic, acidophilic bacterium (Firmicute strain I2511) which was found to couple the oxidation of organic electron donors to the reduction of ZVS and ferric iron. The novel sulfidogen was included in a microbian constium in a low pH "hybrid" sulfidogenic bioreactor (HSB), designed to target the removal of chalcophilic metals from metal-contaminated liquors.

\section{Materials and methods}

2.1. Enrichment, isolation and cultivation of Firmicute 12511

Black sediments collected from an acidic stream draining an abandoned copper mine, Mynydd Parys, North Wales, UK $\left(53^{\circ} 22^{\prime} 59.9988^{\prime \prime} \mathrm{N} ; 4^{\circ} 20^{\prime} 60^{\prime \prime} \mathrm{W}\right)$ that had a distinct hydrogen sulfide odor, were used to enrich acidophilic ZVS-reducers. Ten grams of sediment was added to $100 \mathrm{~mL}$ of liquid medium containing $5 \mathrm{mM}$ glycerol, $0.01 \% \mathrm{w} / \mathrm{v}$, yeast extract; chloride salts medium (g L-1: $0.36 \mathrm{NH}_{4} \mathrm{Cl}, 0.05 \mathrm{KCl}, 0.04 \mathrm{MgCl}_{2} .6 \mathrm{H}_{2} \mathrm{O}, 0.006 \mathrm{Na}_{2} \mathrm{HPO}_{4}, 0.05$ $\left.\mathrm{KH}_{2} \mathrm{PO}_{4}, 0.014 \mathrm{Ca}\left(\mathrm{NO}_{3}\right)_{2} .4 \mathrm{H}_{2} \mathrm{O}\right)$ and $1 \%$, w/v sterile hydrophilic ZVS. To prepare hydrophilic ZVS, sulfur powder (Sigma-Aldrich, UK), which is hydrophobic, was added $(10 \%, w / v)$ to a liquid culture inoculated with the sulfur-oxidizing acidophilic bacterium Acidithiobacillus (At.) thiooxidans, and incubated at $30^{\circ} \mathrm{C}$, shaken at $50 \mathrm{rpm}$, for 7 days, a technique widely reported 
93 to "wet" ZVS, causing it to become hydrophilic. The ZVS was then allowed to settle, removed

94 from the culture, and sterilized at $110^{\circ} \mathrm{C}$ for $60 \mathrm{~min}$.

The enrichment culture was placed in sealed jars under anaerobic atmosphere (Oxoid ${ }^{\mathrm{TM}}$ AnaeroJar ${ }^{\mathrm{TM}}$, Thermo Fisher Scientific; USA) and incubated at $30^{\circ} \mathrm{C}$, shaken at $50 \mathrm{rpm}$.

Hydrogen sulfide production was confirmed by the appearance of CuSprecipitates inside a "copper trap", which consisted of an open universal bottle containin $10 \mathrm{~mL}$ of $20 \mathrm{mM} \mathrm{CuSO}_{4}$ which was placed inside the sealed jar (Supplementary Fig. Wollowing this, the enrichment cultures were streaked onto aSRB plates [13] and incubat ynder anaerobic atmospheres at $30^{\circ} \mathrm{C}$. Single colonies were differentiated by their repologies and purified by repeated restreaking onto fresh solid media. From thes is lates were cultivated in $5 \mathrm{mM}$ glycerol, $0.01 \%$ $(\mathrm{w} / \mathrm{v})$ yeast extract, chloride basal salts, trace elements [13] and $1 \%(\mathrm{w} / \mathrm{v})$ sterile $\mathrm{ZVS} \mathrm{pH} 3$,

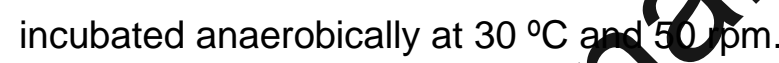

\subsection{Growth Charactexist s of isolate 12511}

\subsubsection{Standard cultivation conditions}

Several attempts to cultivate isolate I2511 in aSRB liquid medium [13] in the absence of ZVS, did not result in increased cell numbers or $\mathrm{H}_{2} \mathrm{~S}$ production. Therefore, it was assumed that the isolate was not able to catalyze the dissimilatory reduction of sulfate. Hence, unless otherwise indicated, the chloride-based basal salts used in the enrichment cultures medium was subsequently replaced by sulfate salts (acidophile basal salts (ABS); [13]). The "standard medium" used to cultivate isolate 12511 contained $5 \mathrm{mM}$ glycerol, $1 \%(\mathrm{w} / \mathrm{v}) \mathrm{ZVS}, 0.01 \%(\mathrm{w} / \mathrm{v})$ yeast extract, ABS and trace elements [13], pH adjusted to 3.0 with sulfuric acid. ZVScontaining and ZVS-free liquid media were heat-sterilized at $110^{\circ} \mathrm{C}$ for $60 \mathrm{~min}$, and $120{ }^{\circ} \mathrm{C}$ for $30 \mathrm{~min}$, respectively. The standard incubation conditions used were anaerobic (generated in sealable jars containing Oxoid ${ }^{\mathrm{TM}}$ AnaeroJar ${ }^{\mathrm{TM}}$ sachets, Thermo Fisher Scientific; USA), 30 ${ }^{\circ} \mathrm{C}$, shaken at $50 \mathrm{rpm}$. Growth was monitored by enumerating cells using a Helber counting 
118 chamber marked with Thoma ruling (Hawksley, UK) and viewed with a Leitz Labolux phase-

119 contrast microscope at a magnification of 400x.

\subsubsection{Growth under aerobic and micro-aerobic conditions}

Growth under aerobic conditions was tested in liquid and on solid media and for microaerobic conditions on solid media only. Micro-aerobic atmosphere was generated in sealable jars containing CampyGen ${ }^{\mathrm{TM}}$ CN25 sachets (Thermo Fisher Scienti USA). The selected solid media used (all overlay) were: YE3ọ and FeSo [14]. Liquid media tested were: (a) ZVS $(1 \%, w / v), 5 \mathrm{mM}$ glycerol and yeast extract $(0.01 \%, \mathrm{w} / \mathrm{v}), \mathrm{pH} 30 \mathrm{Lo}$ (b) $10 \mathrm{mM} \mathrm{Fe}^{2+}$ and yeast extract $(0.02 \%, w / v), p H 2.0$. Solid and liquid media were ifocl ated with culture grown in liquid medium containing ZVS (1\%, w/v), $5 \mathrm{mM}$ glycero (2neast extract $(0.01 \%$, w/v) pH 3.5, incubated anaerobically. To evaluate grow ip liquid media, planktonic bacterial cells were counted and $\mathrm{pH}$ measured after 10 and 20 days.

\subsubsection{Carbon metabolism}

To investigate whethe is late 2511 required yeast extract for growth, isolate I2511 was grown in standerd (iqu) medium with or without yeast extract. Planktonic cells were enumerated after 11 and 18 days. The effect of different concentrations $(0.005$ or $0.05 \%$, w/v) of yeast extract or peptone on cell yields was tested in replicate liquid cultures. Two other liquid culture variants were set up: (a) $0.05 \%$ (w/v) yeast extract or peptone but no ZVS; (b) standard medium with $0.005 \%(\mathrm{w} / \mathrm{v})$ yeast extract. Planktonic cells were enumerated after 18 days.

The ability of isolate 12511 to grow on a range of defined small molecular weight organic compounds was tested in replicate liquid cultures containing ABS and trace elements, $1 \%$ $(\mathrm{w} / \mathrm{v}) \mathrm{ZVS}, 0.01 \%(\mathrm{w} / \mathrm{v})$ yeast extract $\mathrm{pH} 3.0$ supplemented with the following compounds: glucose, fructose, 1,3-propanediol, glycerol, lactic acid and citric acid (all at $5 \mathrm{mM}$ ); ethanol and methanol (both at $10 \mathrm{mM}$ ). In parallel, control cultures were set up containing ZVS and $0.01 \%$ $(w / v)$ yeast extract with no additional organic electron donor. To assess growth by fermentation, replicate cultures were supplemented with glucose, glycerol, L-malate or 
144 fumarate (all at $5 \mathrm{mM}$ ) in the absence of ZVS at pH 4. Growth was assessed from counts of

145 planktonic cells after incubating for 12 - 18 days.

\subsubsection{The use of alternative electron acceptors by isolate 12511}

Dissimilatory reduction of ferric iron was tested by growing strain 12511 in liquid medium containing $5 \mathrm{mM}$ glycerol and $0.005 \%$ (w/v) yeast extract and $\sim 15 \mathrm{mM} \mathrm{Fe}_{2}\left(\mathrm{SO}_{4}\right)$. The $\mathrm{pH}$ was adjusted to 2.6 with sterile $1 \mathrm{M} \mathrm{NaOH}$, which caused partial precipitation of the ferric iron. Cultures were incubated in sealed jars under anaerobic atmosphenticate cultures were inoculated with an active culture of strain 12511 , grown previous $\mathrm{y}$ in the presence of ferric iron.

\subsubsection{Effect of $\mathrm{pH}$ and temperature on the growth rate of isolate $\mathrm{I} 2511$}

Replicated non-inoculated controls were set up in paralle. Kerrous iron concentrations and culture $\mathrm{pH}$ were determined after 17,25 and 30 days

To determine whether strain 12511 could catalyze the dissimilatory reduction of tetrathionate, thiosulfate, cysteine or figte, replicate cultures were incubated anaerobically at $30^{\circ} \mathrm{C}$ in aSRB medium supgrenented with either $5 \mathrm{mM}$ potassium tetrathionate, $10 \mathrm{mM}$ sodium thiosulfate, $0.02 \%$ (w) L-cysteine hydrochloride monohydrate or $10 \mathrm{mM}$ sodium nitrate. Positive (ZVS colathing) and negative (no electron acceptor) controls were set up in parallel. Growth was evaluated by enumerating planktonic cells.

Isolate I2511 was grown in a pH- and temperature-controlled bioreactor (FerMac 310/60 unit, Electrolab Biotech, UK) fitted with a $2.2 \mathrm{~L}$ glass vessel and stirred at $150 \mathrm{rpm}$. The standard liquid medium was slightly modified by including less yeast extract $(0.005 \%$, w/v). A continuous stream of oxygen-free nitrogen (OFN, at $\sim 200 \mathrm{~mL} \mathrm{~min}^{-1}$ ) was used to maintain anaerobic conditions and to deliver $\mathrm{H}_{2} \mathrm{~S}$ generated inside the bioreactor vessel to an off-line glass vessel that contained $500 \mathrm{~mL}$ of $20 \mathrm{mM} \mathrm{CuSO}_{4}$. To determine the effect of $\mathrm{pH}$ on the growth rate of isolate 12511 , this was varied between 2.8 and 4.5 and the bioreactor maintained at $30 \stackrel{\circ}{\circ}$. To determine the effect of temperature on the growth rate of isolate 12511 , this was 
170 varied between $23^{\circ} \mathrm{C}$ and $35^{\circ} \mathrm{C}$ and the bioreactor maintained at $\mathrm{pH}$ 3.7. Samples from the

171 bioreactor vessel and the off-line vessel were removed regularly to determine concentrations

172 of glycerol, acetic acid and copper. Semi-logarithmic plots of glycerol oxidized against time 173 were used to determine growth rates. Rates of $\mathrm{H}_{2} \mathrm{~S}$ production were determined by changes 174 in concentrations of copper in the off-line vessel. Additional tests were carried out to assess

175 the minimum $\mathrm{pH}\left(\right.$ at $30^{\circ} \mathrm{C}$ ) and maximum temperature (at $\mathrm{pH} 3.7$ ) at which isolate $\mathrm{I} 2511$ could 176 grow. Growth was evaluated by counting planktonic bacterial cello atte 11 and 18 days of 177 incubation.

\subsubsection{Dissimilatory reduction of zero-valent sulfur on solid medium}

Reduction of ZVS on solid media was arsesed by streaking liquid culture of strain I2511 onto an overlay ZVS (S ${ }^{0}$ o) plates, deloped jointly with Ivan Nancucheo (Facultad de Ingeniería y Tecnología, Universidad San Sebastian, Chile). The $\mathrm{S}^{0} \underline{0}$ plate contained $5 \mathrm{mM}$ glycerol, $0.01 \%(\mathrm{w} / \mathrm{v})$ yeast extrad, choride basal salts, $0.5 \%(\mathrm{w} / \mathrm{v})$ agarose, adjusted to $\mathrm{pH}$ 3.0 with hydrochloric acid, to with, after setting, $100 \mu \mathrm{L}$ of a suspension of ZVS $(40 \%, \mathrm{~m} / \mathrm{v})$ was spread on the Ingculated plates were placed in sealed jars, incubated under an anaerobic atmospherelogether with a universal bottle containing $20 \mathrm{mM}$ copper sulfate to indicate production of $\mathrm{H}_{2} \mathrm{~S}$, incubated at $30^{\circ} \mathrm{C}$.

\subsubsection{Tolerance to copper, sodium chloride and acetic acid}

Replicate cultures of 12511 in standard medium ( $\mathrm{pH} 2.5)$ were supplemented with copper sulfate (at $0.1,1.0,5.0$ and $10 \mathrm{mM}$ ) to assess tolerance to $\mathrm{Cu}^{2+}$. Copper-free control cultures were set up in parallel. Growth was assessed by enumerating planktonic cells and from formation of CuS (as a result of production of $\mathrm{H}_{2} \mathrm{~S}$ ). A similar approach was used to determine the tolerance to sodium chloride $(50,100$ and $500 \mathrm{mM})$. To investigate tolerance of strain I2511 to acetic acid, replicate cultures containing $0.5,1.0$ and $3.0 \mathrm{mM}$ acetic acid were set up in standard medium at $\mathrm{pH} 2.5$, together with acetic acid-free controls. 
2.3.

Relative abundance of isolate $\mathrm{I} 2511$ in a low pH sulfidogenic bioreactor

Isolate I2511 was included in a microbial consortium in a low pH "hybrid" sulfidogenic bioreactor (HSB). The design of the HSB, and its effectiveness in removing contaminant transition metals from neutral $\mathrm{pH}$ mine waters, are detailed in [15]. The HSB contained both ZVS and sulfate as potential electron acceptors, and glycerol and yeast extract were provided as electron donors/carbon sources. The bioreactor (an upflow biofilm bed sulfidogenic bioreactor of the $2.2 \mathrm{~L}$ working volume) was operated at $30^{\circ} \mathrm{C}$, agitated at $50 \mathrm{rpm}$ in continuous flow mode with a feed solution containing $2 \mathrm{mM}$ glycerol, $0.01 \%(\mathrm{w} / \mathrm{v})$ yeast extract, ABS with $\mathrm{pH}$ adjusted to either 2.0 or 2.5 with sulfuric acid. The composition grobial populations in the HSB, both planktonic and sulfur-attached cells, were analyz d. samples were taken from the surface liquor of the bioreactor and from the ZVS layer any theated as previously described [15]. DNA from the biomass was extracted using Poyer Soil UlwaClean microbial DNA isolation Kits (QIAGEN, Denmark), following manufargen ế instructions. Bacterial and archaeal 16S rRNA genes were amplified and analyzed terminal restriction enzyme fragment length polymorphism (T-RFLP; [16]), a spryantitative approach used to calculate relative abundances in microbial comminies.

\subsection{Biomolecular Anarysis}

Genomic DNA was extracted from liquid cultures using modified CTAB/high-salt extraction, followed by alcohol precipitation [17]. The 16S rRNA gene of strain I2511 was

amplified using 27F (5'-3' AGAGTT TGATCM TGGCTCAG) and 1387R (5'-3' GGGCGGWGTGTACAAGGC) primers and PCR products were sequenced by Sanger method (Macrogen Inc., South Korea) and analyzed by T-RFLP [16]. The draft genome sequence of strain I2511 (GenBank accession number QXHL00000000) indicated only one $16 \mathrm{~S}$ rRNA gene copy to be present, enabling more accurate calculation of relative abundances using T-RFLP analysis. 
226 The 16S rRNA gene sequence of strain I2511 was deposited in the GenBank 227 database and compared with those of related species (retrieved from EZBioCloud;[18]).

228 Multiple sequence alignment was performed using SINA [19]. The phylogenetic analysis was 229 performed by MEGAX with the Maximum Likelihood method implemented [20]. Selection of 230 best-fitting substitution models was performed with the Bayesian Information Criterion using bootstrap analysis using 1000 replicates.

\section{Analytical methods}

The $\mathrm{pH}$ of liquid cultures were measured using a pHase coupled to an Accumet $50 \mathrm{pH}$ meter. Concentrationerf glycerol, sulfate, and acetic acid were determined by ion chromatography [6] griventrations of ferrous iron determined using the Ferrozine assay [22]. Concentrations of so wuble copper were measured using a

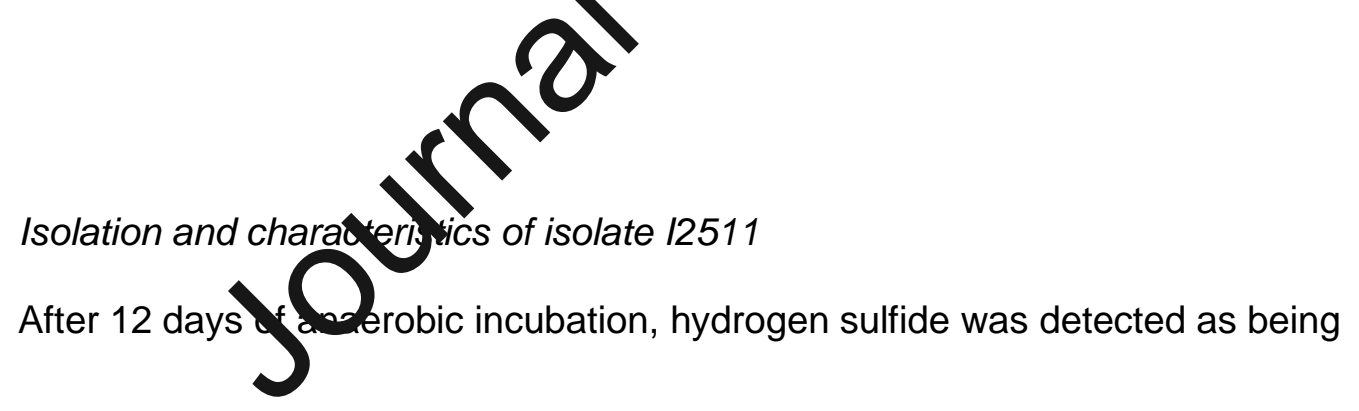

231 Model Selection implemented in iQtree [21]. Tree topology reliabilities were confirmed by 232

2332.6.

colorimetric assay [23].

3. Results 
242 generated by liquid enrichment cultures of the black sediments in ZVS-glycerol medium.

243 Single colonies from aSRB plates streak-inoculated from the enrichment cultures were put 244 into standard ZVS medium, and one of these (I2511) was able to generate $\mathrm{H}_{2} \mathrm{~S}$. T-RFLP 245 analysis confirmed purity of the culture. Cells were motile rods ( $3-5 \mu \mathrm{m}$ long and $\sim 0.4 \mu \mathrm{m}$ 246 wide) that formed oval endospores located at the cell termini. Isolate I2511 produced very

247 small off-white colonies ( $\leq 1 \mathrm{~mm}$ diameter) on aSRB solid medium but these were not 248 encrusted with $\mathrm{ZnS}$, a feature indicative of sulfate-reducers [13]. Strain I2511 also produced 249 small white colonies on $\mathrm{S}^{0}$ o plates, and generated $\mathrm{H}_{2} \mathrm{~S}$ (confirmed by formation of CuS in a 250 universal bottle containing $\mathrm{CuSO}_{4}$ ). ZVS particles disappeared where colonies grew, 251 indicating they were being used to generate $\mathrm{H}_{2} \mathrm{~S}$ (Supplementary Fig. 2). No growth of 
252 isolate was observed under aerobic or micro-aerobic conditions, confirming that it is an

253 obligate anaerobe.

254

\subsection{Phylogenetic and genomic analysis}

256

The partial 16S rRNA gene sequence of isolate I2511 (1,388 bp) was deposited in

257 GenBank (accession number KY576736). Analysis of its 16S rRNA gene sequence showed that isolate 12511 was a member of the phylum Firmicutes (order Bacillales, family Alicyclobacillaceae) and its closest validated relatives were Alicyclobacillus contaminans $3 \mathrm{~A} 191^{\top}$ and Alicyclobacillus tolerans $\mathrm{K} 1^{\top}$, which shared $92.9 \%$ and 90.9 sequence similarity to isolate I2511, respectively. Isolate IR2 and clone G13 were non closely related bacteria, both sharing $96 \%$ identity of their 16 S rRNA genes to st an $\$ 511$. Strain IR2 was isolated from a sulfidogenic bioreactor inoculated with enrighment celture containing biomass of an acidic stream draining a copper mine [6] clone G13 was obtained from glucose enrichment culture inoculated with acidic me tailings containing high concentrations of methylmercury [24]. Phylogenetic an of the 16S rRNA gene of strain I2511 showed that the isolate clustered with strain and clone $\mathrm{G} 13$ in a separate clade from that represented by the closest validated A/raclgacillus species. The phylogenetic relationship of 12511 with the validated species of thenus Alicyclobacillus and closely related bacteria is shown in Fig. 1.

\subsection{Carbon metabolism}

There were no increase in cell numbers of isolate 12511 in media where glycerol was the only carbon source provided. However, the isolate grew in glycerol medium that also contained yeast extract, and in medium containing only either yeast extract or peptone as carbon source/electron donor, both of which were also coupled to the reduction of ZVS, generating $\mathrm{H}_{2} \mathrm{~S}$. Isolate 12511 grew on a range of organic compounds (Supplementary Fig. 3), all of which were coupled to the dissimilatory reduction of ZVS. Lactic acid was not utilized, 
and cell numbers were less than in control cultures. The isolate was not able to grow by fermentation of yeast extract or of any of the defined organic substrates tested.

280

281

282

283

284

285

286

287

288

289

290

291

292

293

294

295

296

297

298

299

300

301

302

303

304

\subsection{Alternative electron acceptors}

Cultures of I2511 containing glycerol and ferric iron (mostly present as a solid phase)

but no ZVS showed increases in both $\mathrm{pH}$ and $\mathrm{Fe}^{2+}$ concentrations after 17 days of incubation, but beyond this cell number increases were only marginal, and yeast extract $(0.005 \%, \mathrm{v} / \mathrm{v})$ added at day 25, did not induce further iron reduction (Fig. 2). Minor changes in $\mathrm{pH}$ and $\mathrm{Fe}^{2+}$ concentrations were measured in non-inoculated cultures dufing the same time. Concentrations of glycerol oxidized and acetic acid produced after $2 \mathrm{dg} y$ s were $0.54 \mathrm{mM}$ and $0.51 \mathrm{mM}$, respectively.

In contrast, media containing either tetrathionate of thosulfate as potential alternative electron acceptors to ZVS had similar cell counts negative (ZVS-free) control cultures. Similarly, cell numbers did not increase a d $\mathrm{H}$ did not change in cultures amended with cysteine. Cell numbers in nitrate-amended cultures were slightly more than in controls but far fewer than those in ZVS-containingrcL (ty res. In a repeat of this experiment, no increases in cell numbers were observed. Fin mese experiments, it was concluded that isolate could use ferric iron as an alternatiredron acceptor to ZVS, but not tetrathionate, thiosulfate, nitrate or cysteine.

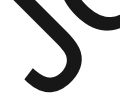

\subsection{Effect of $\mathrm{pH}$ and temperature on growth rates}

Growth experiments showed that hydrogen sulfide production was correlated with both glycerol oxidation $(r=0.93)$ and planktonic cell numbers $(r=0.91)$ (Fig. 3). Concentrations of acetic acid increased with time, and the ratio of acetic acid produced to glycerol oxidized was $\sim 0.4$ (Fig. 4). When incubated at $30^{\circ} \mathrm{C}$, isolate $\mathrm{I} 2511$ had an optimum growth at $\mathrm{pH} \sim 3.7$ with a culture doubling time of $\sim 62 \mathrm{~h}$ (Fig. 5). Under optimum $\mathrm{pH}(3.7)$ and $35^{\circ} \mathrm{C}$, its culture doubling time was $54 \mathrm{~h}$, corresponding to a $\mu_{\max }$ of $0.01 \mathrm{~h}^{-1}$. Isolate 12511 did not grow (or generate $\mathrm{H}_{2} \mathrm{~S}$ ) at temperatures $\geq 38^{\circ} \mathrm{C}$, and below $23^{\circ} \mathrm{C}$ growth was very slow (doubling time $\sim 80 \mathrm{~h}$; at $\mathrm{pH}$ 3.7 and $23^{\circ} \mathrm{C}$ ). No growth or $\mathrm{H}_{2} \mathrm{~S}$ production was observed at $\mathrm{pH} 2.5$ and $30^{\circ} \mathrm{C}$ in bioreactor 
cultures. However, tests carried out in universal bottles, where $\mathrm{pH}$ was not controlled, suggested that the isolate was able to generate $\mathrm{H}_{2} \mathrm{~S}$ in media poised initially at 1.8 (Supplementary Fig 4).

\section{Tolerance to copper, sodium chloride and acetic acid}

Isolate I2511 was highly sensitive to both copper (II) ions and salt $(\mathrm{NaCl})$, with growth being inhibited by the lowest concentrations of these $(0.1$ and $50 \mathrm{mM}$, respectively) tested. All cultures supplemented with acetic acid had lower cell counts than the control culture at same $\mathrm{pH}$ after 10 days of incubation, though by day 15 cultures containing 0.5 and $1.0 \mathrm{mM}$ acetic acid had similar planktonic cell counts to the control cultures at the ame

Fig. 5). Growth of strain 12511 was completely inhibited by 3 (M cetic acid. Culture $\mathrm{pH}$ at day 15 for all tests (including control) were similar at pH 2.0

3.7. Relative abundance of isolate 12511 in a low

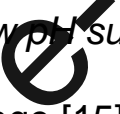

While the HSB operated over a wide or range [15] there was particular interest in the microbial community composition when was werated at extremely low $\mathrm{pH}$. Prior to the start of experiment, the bioreactor was allacy to adapt to the operating conditions for 20 days for the $\mathrm{pH} 2.5$ feed liquor, and for 16 doys for the $\mathrm{pH} 2.0$ feed liquor. With $\mathrm{pH} 2.5$ feed liquor, the $\mathrm{pH}$ within the vessel was 3 . 3 when using $\mathrm{pH} 2.0$ feed liquor the bioreactor $\mathrm{pH}$ ranged from 1.98 - 2.05. Hy rogeh sulfide was generated throughout both experiments, but no significant differences in rates were found when using pH 2.0 and $\mathrm{pH} 2.5$ feed liquors (ttest: $t(11)=0.30, p=0.77$; Supplementary Fig. 6). Changes in rates of sulfate reduction and $\mathrm{H}_{2} \mathrm{~S}$ production using pH 2.5 and pH 2.0 feed liquors are shown in Supplementary Fig. 7.

Some of the sulfate present in the $\mathrm{pH} 2.5$ influent liquor was reduced (these accounted for 77 $\pm 8 \%$ of the $\mathrm{H}_{2} \mathrm{~S}$ produced), but there was no detectable net sulfate reduction when the bioreactor $\mathrm{pH}$ equilibrated at $~ 2.0$.

The microbial communities that were attached to ZVS particles in the HSB were similar to those of planktonic bacteria at both $\mathrm{pH}$ values, though there were major differences in the dominant bacteria present (Fig. 6). At pH 2.6, the sulfate-reducing bacteria Peptococcaceae 
CEB3 [1] and D. acididurans were found to be the dominant bacteria, but at $\mathrm{pH} \sim 2.0$ neither of these was detected, and the most abundant bacterium was strain 12511 (51\% relative abundance in the liquid phase and $55 \%$ of the attached community), and the facultative anaerobe At. ferrooxidans and a putative fermentative Clostridium sp. were also

detected.

\section{Discussion}

This study has shown that a novel mesophilic acidophilic isolate of the phylum Firmicutes, strain 12511 , was able to generate hydrogen sulfide at low $\mathrm{gH}$, via the dissimilatory reduction of ZVS. This is only the second non sulfate-reducing acidonto be demonstrated to have this trait, and the data show that 12511 is far more tolerant extreme acidity than Ds. amilsii [7]. The isolate was an obligately anaerobe that (Ne other Firmicutes) formed endospores, and was also an obligate heterotroph. The only ther electron acceptor that I2511 used (of those tested) was ferric iron. This possibs (accounts for its initial growth on solid media that contained iron but not ZVS (at the $\mathrm{PH}$ of the aSRB plates there would be some anticipated oxidation of $\mathrm{Fe}^{2+}$ to $\mathrm{Fe}^{3+}$ during preation and storage). Rigorous testing confirmed that I2511 was not able to use sulfat terathionate, thiosulfate or nitrate as a terminal electron acceptor, or grow via fermengtion. Isolate 12511 was able to use a variety of organic compounds but requinedverst extract for growth. It oxidized glycerol incompletely, generating acetic acid, but not instoichiometric amounts. The isolate was mesophilic, with no growth observed at a maximum temperature $38^{\circ} \mathrm{C}$. Its $\mathrm{pH}$ optimum was 3.7 , categorizing it as a moderate, rather than an extreme acidophile [25]. Although it did not grow in the fixed $\mathrm{pH}$ bioreactor at $\mathrm{pH} 2.5$, data from the HSB (and to a lesser extent from the batch culture experiment in universal bottles) suggested that it may be capable of growth-decoupled sulfidogenesis at $\mathrm{pH}$ values less than 2 . This apparent discrepancy might be explained by carryover of acetic acid in the bioreactor when setting up a new growth test (generally $~ 80 \%$ of the bioreactor was drained and replaced with fresh medium) which at the HSB in the $\mathrm{pH} 2.0$ 
feed liquor test, acetic acid concentrations were low $(\leq 0,31 \mathrm{mM})$. Generating $\mathrm{H}_{2} \mathrm{~S}$ at low $\mathrm{pH}$ is an unusual and relatively rare trait (for acidophilic bacteria, though not for acidophilic archaea) that could be useful in the development of sulfidogenic biotechnologies used to treat acidic, metal-rich effluents.

Phylogenetic analysis of the 16S rRNA gene of strain I2511 showed that the isolate clustered in a separate clade from that represented by the closest validated Alicyclobacillus species. Some characteristics of strain I2511 (i.e. a mesophilic obligate anaerobe, which catalyzes the dissimilatory reduction of both ZVS and ferric iron and has relatively low tolerance to copper and sodium chloride) are distinct from its closest known relatives Alb. contaminans $^{\top}$ and Alb. tolerans ${ }^{\top}$. For example, Alb. contaminans ${ }^{\top}$ is a foderately thermophilic strict aerobe, and tolerates up to $\sim 350 \mathrm{mM} \mathrm{NaCl}$. Alb. tolerans ${ }^{\top}$ is $\mathrm{m}$ derately thermophilic facultative anaerobe and grows as a heterotroph and also autot ondcally using $\mathrm{Fe}^{2+}$ and ZVS as electron donors. The acidophilic genera of the family (lic) clobacillaceae (Alicyclobacillus, Sulfobacillus and "Acidibacillus") share several Detracteristics. Many species are strict aerobes, others are facultative anaerobes and use either molecular oxygen or ferric iron as electron acceptors, many are thermo-tolexant or moderately thermophilic, several are obligate heterotrophs, some are facultative auterophs, some species can use ferrous iron or reduced sulfur as electron donors, and o splay elevated tolerance to transition metals. However, none of the species described can grow anaerobically by sulfur respiration, which clearly delineates isolate 125 (which is a strict anaerobe) from other species of the family Alicyclobacillaceae.

While more research is required in order to validate isolate 12511 , the data suggest that it is the first cultivated species of a novel genus within the phylum Firmicutes. Questions about how it interacts with other microorganisms in the wider environment need also to be addressed, along with more work on examining its potential for bioremediation of polluted environments. 
385

386 Conflict of interest 
388 The authors confirm that there are no conflicts of interest.

389

390

Acknowledgements

391

392

Roseanne Holanda is grateful to the National Council of Technological and Scientific 393

Development (Brazil) for provision of a research studentship.

394

395

Appendix A. Supplementary data

396

397

398

399

[1] Johnson DB, Sánchez-Andrea I. Ding ilatory reduction of sulfate and zero-valent sulfur at low $\mathrm{pH}$ and its significance oromediation and metal recovery. Adv Microb Physiol

[2] Mori K, Kim H, Kanderea T, Hanada S. A novel lineage of sulfate-reducing

\section{References}

400

401

402

403

2019;75:205-231.

404

405 microorganisms: Thermodesulfobiaceae fam. nov., Thermodesulfobium narugense, gen. 406 nov., sp. nov., a new thermophilic isolate from a hot spring. Extremophiles 2003;7:283290. 
[3] Kimura S, Hallberg KB, Johnson DB. Sulfidogenesis in low pH (3.8 - 4.2) media by a 409 mixed population of acidophilic bacteria. Biodegradation 2006;17:57-65. [4] Alazard D, Joseph M, Battaglia-Brunet F, Cayol JL, Ollivier B. Desulfosporosinus acidiphilus sp. nov.: a moderately acidophilic sulfate-reducing bacterium isolated from acid mining drainage sediments. Extremophiles 2010;14:305-312. 
413 [5] Sánchez-Andrea I, Stams AJ, Hedrich S, Ňancucheo I, Johnson DB. Desulfosporosinus acididurans sp. nov.: an acidophilic sulfate-reducing bacterium isolated from acidic sediments. Extremophiles 2015;19:39-47.

[6] Ňancucheo I, Johnson DB. Selective removal of transition metals from acidic mine waters by novel consortia of acidophilic sulfidogenic bacteria. Microb Biotechnol 2012; 5:34-44.

[7] Florentino AP, Brienza C, Stams AJ, Sánchez-Andrea I. Desulfurella amilsii sp. nov., a

[8] Frolov EN, Kublanov IV, Toshchakov SV, Samarov NI, Novikov AA, Lebedinsky AV, et al. Thermodesulfobium acidiphilum sp. nov thenoacidophilic, sulfate-reducing, chemoautotrophic bacterium from a therny site. Int J Syst Evol Microbiol 2017; 67:14821485.

[9] Rüffel V, Maar M, Dammbrück (N) Aauröder B, Neu TR, Meier J. Thermodesulfobium sp. strain 3baa, an acidophilic sulfate reducing bacterium forming biofilms triggered by mineral precipitation. Microbiol 2018;20:3717-3731.

[10] Golyshina OV, Fer er M, Golyshin PN, Diversity and physiologies of acidophilic archaea, in Quatrini R, Johnson DB (Eds), Acidophiles: Life in Extremely Acidic Environments, Caister Academic Press, Norfolk, 2016, pp 93-106.

[11] Santos AL, Johnson DB. Design and application of a low pH upflow biofilm sulfidogenic bioreactor for recovering transition metals from synthetic waste water at a Brazilian copper mine. Front Microbiol 2018;9:2051.

[12] Bratty M, Lawrence R, Kratochvil D, Marchant B. Applications of biological $\mathrm{H}_{2} \mathrm{~S}$ production from elemental sulfur in the treatment of heavy metal pollution including acid 

rock drainage, in Proceedings of the 7th International Symposium of Acid Rock Drainage (ICARD), St. Louis, MO, 2006, pp 271-281.

[13] Ňancucheo I, Rowe OF, Hedrich S, Johnson DB. Solid and liquid media for isolating and cultivating acidophilic and acid-tolerant sulfate-reducing bacteria. FEMS Microbiol Lett 2016;363:1-6.

[14] Johnson DB, Hallberg KB. Techniques for detecting and identifying acidophilic mineraloxidising microorganisms. In: Rawlings DE, Johnson DB, editors. Biomining. Heidelberg: Springer-Verlag; 2007, p 237-62.

[15] Holanda R, Johnson DB. Removal of zinc from circum-ne tral ph mine-impacted waters using a novel "hybrid" low pH sulfidogenic bioreactor Pront Environ Sci 2020; 8:22.

[16] Kay C, Rowe O, Rocchetti L, Coupland K ARtiberg KB, Johnson, DB. Evolution of microbial "streamer" growths in an acidc, metal-contaminated stream draining an abandoned underground copper mike. Life 2013;3:189-210.

[17] Wilson K. Preparation of gen mictNA from bacteria. Curr Protoc Mol Biol 2001;2:2-4.

[18] Yoon S-H, Ha S-M, KwonS, Lim J, Kim Y, Seo H, et al. Introducing EzBioCloud: a taxonomically unitodatabase of $16 \mathrm{~S}$ rRNA gene sequences and whole-genome assemblies. Int Syst Evol Microbiol 2017;67:1613-1617.

[19] Pruesse E, Peplies J, Glöckner FO. SINA: accurate high throughput multiple sequence alignment of ribosomal RNA genes. Bioinformatics 2012;28:1823-1829.

[20] Kumar S, Stecher G, Li M, Knyaz C, Tamura K. MEGA X: Molecular Evolutionary Genetics Analysis across computing platforms. Mol Biol Evol 2018;35:1547-1549.

[21] Trifinopoulos J, Nguyen LT, von Haeseler A, Minh BQ. W-IQ-TREE: a fast online phylogenetic tool for maximum likelihood analysis. Nucl Acids Res 2016;44(W1): W232- 

W235. 
461 [22] Stookey L. Ferrozine e a new spectrophotometric reagent for iron. Anal Chem 462 1970;42:779-81.

463 [23] Anwar MA, lqbal M, Qamar MA, Rehman M, Khalid AM. Technical communication: 464 determination of cuprous ions in bacterial leachates and for environmental monitoring. World J Microbiol Biotechnol 2000;16(2):135-8.

[24] Winch, S., Mills, H.J., Kostka, J.E., Fortin, D. and Lean, D.R.S. Identification of sulfate467 reducing bacteria in methylmercury-contaminated mine tailings by analysis of

rRNA genes. FEMS Microbiol Ecol 2009; 68:94-107.

[25] Johnson DB, Quatrini R. Acidophile Microbiology in Space nno Time. Curr Issues Mol

Figure 1. Phylogenetic nal sis by the Maximum Likelihood method showing the relationship of isolate I2511 16S rRA A gene sequences to closely related bacteria and validated species SSU

468

469

470

Biol 2020;39:63-76.

471 
477 of the genus Alicyclobacillus. The support in bootstrap analysis (1000 replicates) with values

$478 \geq 50 \%$ are indicated by "•". The bar represents 0.05 substitutions per site. The $16 \mathrm{~S}$ rRNA

479 gene sequence of Sulfobacillus thermosulfidooxidans ${ }^{\top}$ (NR040945) was used as the 480 outgroup.

481 Figure 2. Reductive dissolution of solid phase ferric iron by isolate I2511 (solid lines) and 482 noninoculated cultures (broken lines) after 17,25 and 30 days of incubation at $30^{\circ} \mathrm{C}$. Key: indicate data ranges $(n=2)$. 
485 Figure 3. Relationship between hydrogen sulfide production and glycerol oxidation $(\mathbf{\Lambda} ; r=$

486 0.93) and hydrogen sulfide production and planktonic cell numbers $(\bullet ; r=0.91)$ when isolate 487 I2511 was grown in a bioreactor at $\mathrm{pH} 3.2$ and $30^{\circ} \mathrm{C}$.

488 Figure 4. Cumulated amounts of hydrogen sulfide produced ( $\mathbf{\square})$, glycerol oxidised ( $\mathbf{A})$ and 489 acetic acid produced $(\bullet)$ of isolate at $\mathrm{pH} 2.8$ and $30^{\circ} \mathrm{C}$.

490 Figure 5. Effect of $\mathrm{pH}$ on the culture doubling times $\left(\mathrm{t}_{\mathrm{d}}\right)$ of isolate $\mathrm{I} 2511$ at fixed temperature $491\left(30^{\circ} \mathrm{C}\right)$.

Figure 6. T-RFLP profiles of bacterial 16S rRNA genes amplified from extracts and digested with the restriction enzyme Haell during experiments pe ating the HSB at low pH in continuous flow mode. "Sulfur phase" corresponds to DNA extracted from sulfur-attached bacterial communities. "Liquid phase" corresponds to fa extracted from planktonic cells. 
496

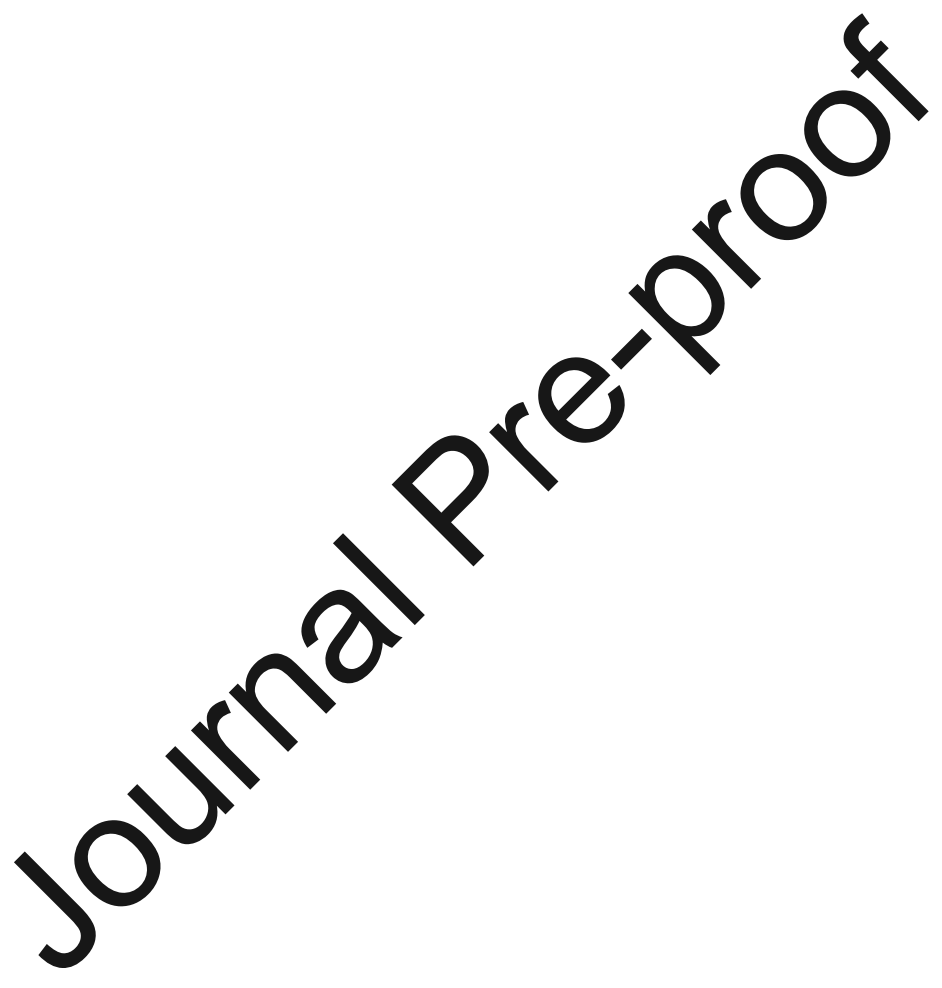




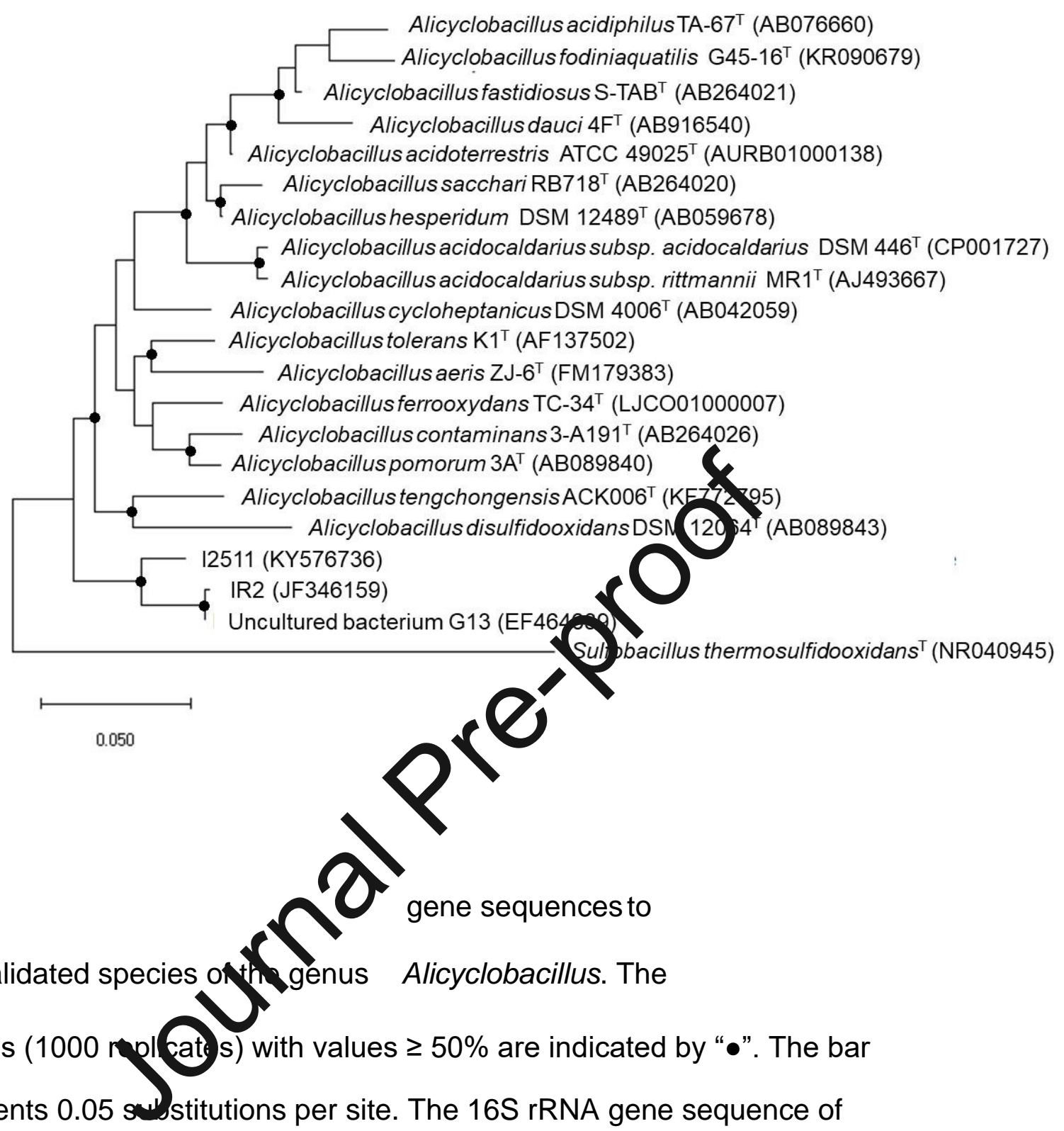

represents 0.05 stitutions per site. The 16S rRNA gene sequence of Figure 1. Phylogenetic analysis by the Maximum Likelihood method showing the relationship of isolate I2511 $16 \mathrm{~S}$ rRNA closely related bacteria 
and

support in bootstrap

Sulfobacillus thermosulfidooxidans ${ }^{\top}$ (NR040945) was used as the outgroup. 


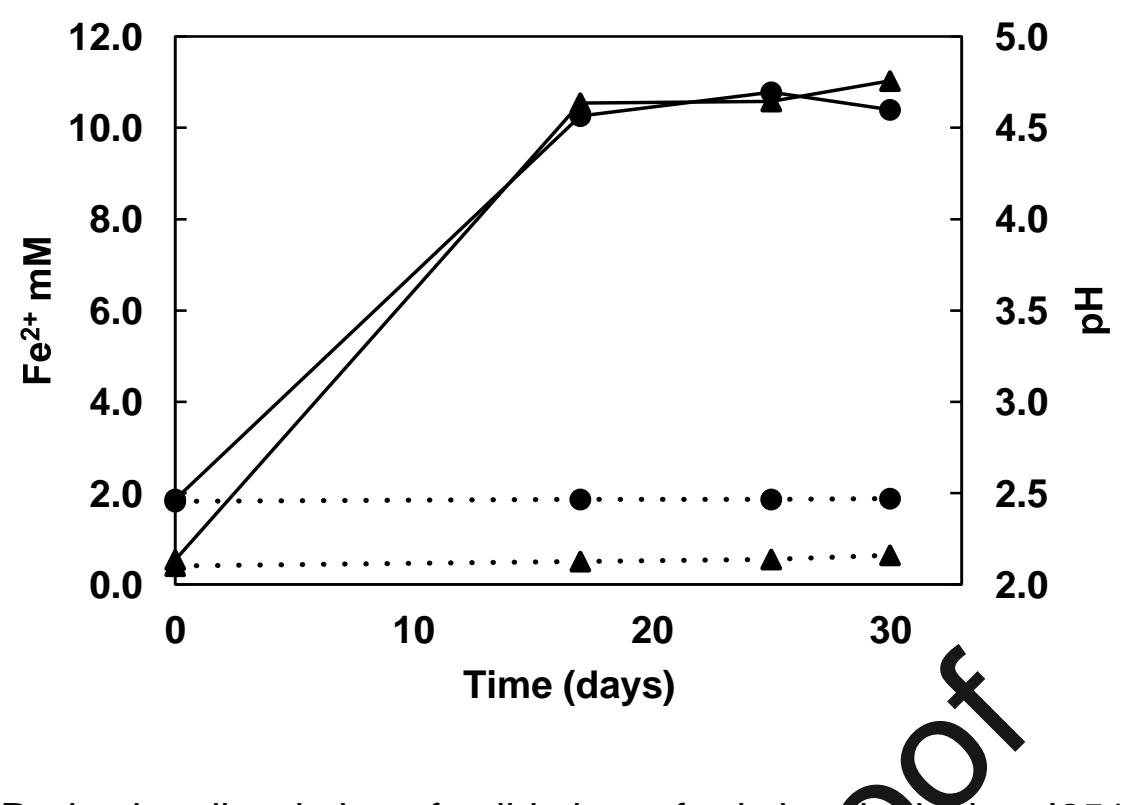

Figure 2. Reductive dissolution of solid phase ferric iror by solate I2511 (solid lines) and non -inoculated cultures (broken lines) (tE 7,25 and 30 days of incubation at $30^{\circ} \mathrm{C}$. Key: ( $\left.\boldsymbol{\Delta}\right)$ ferrous iron cor Cemtrations $(\mathrm{mM})$ and $(\bullet) \mathrm{pH}$. Bars show mean values and error bars ind cate ata ranges $(n=2)$. 

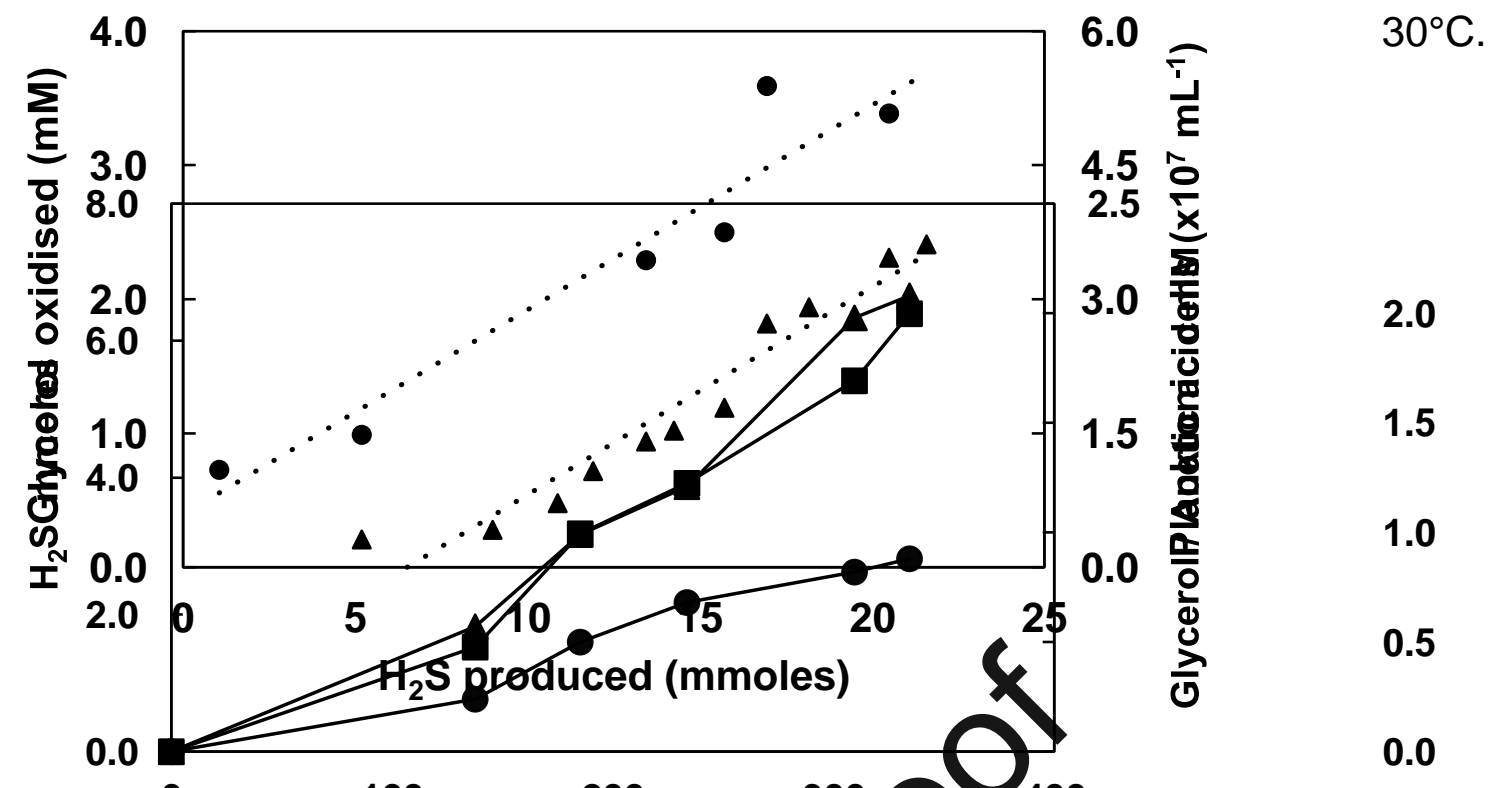

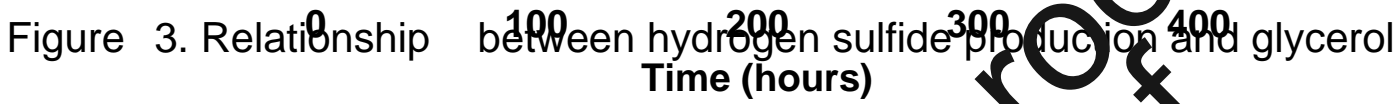

oxidation ( $\mathbf{\Delta} ; r=0.93$ ) and hydrogen sulfide pror ucion a antanktonic cell

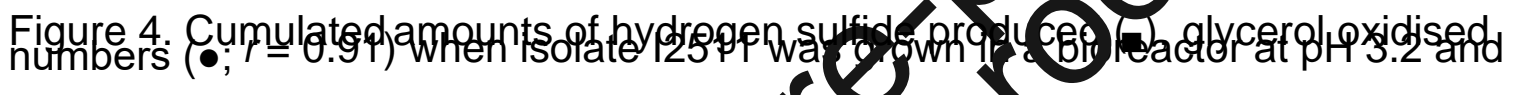

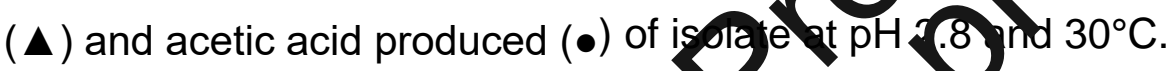

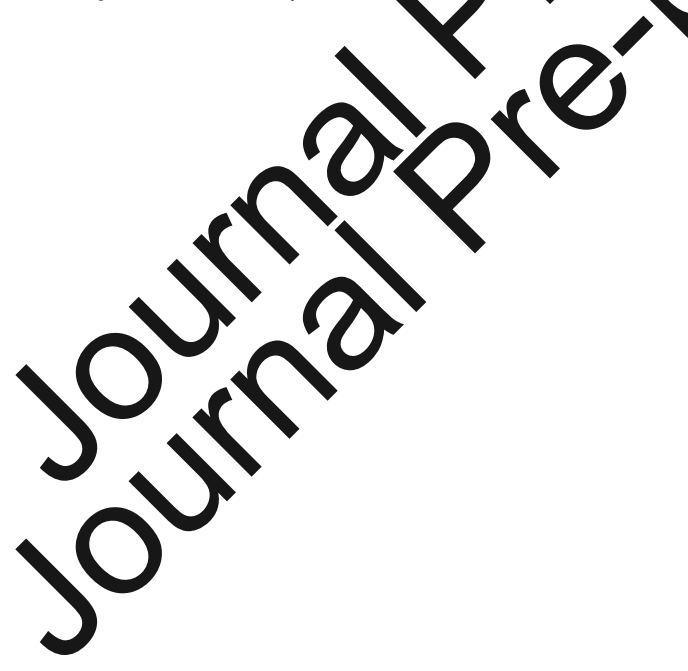




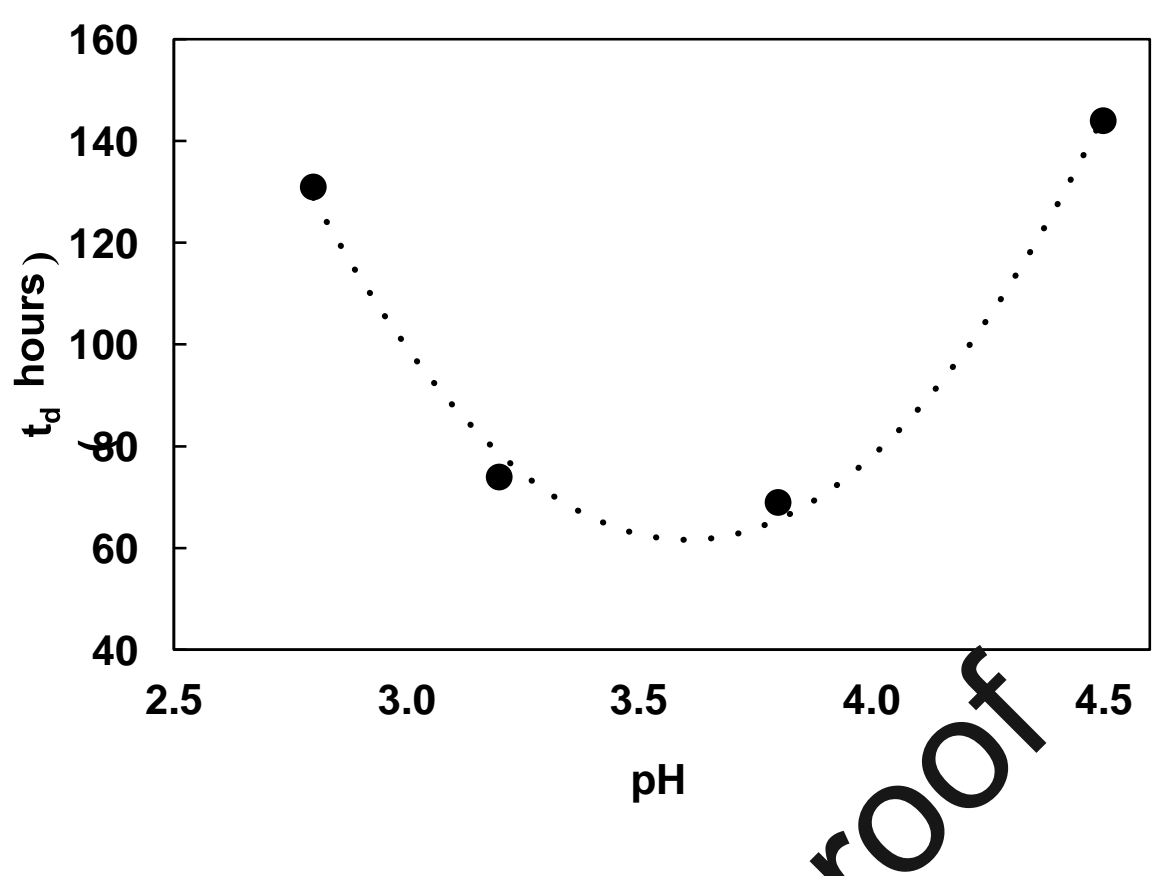

Figure 5. Effect of $\mathrm{pH}$ on the culture doubling times of isolate $\mathrm{I} 2511$ at fixed

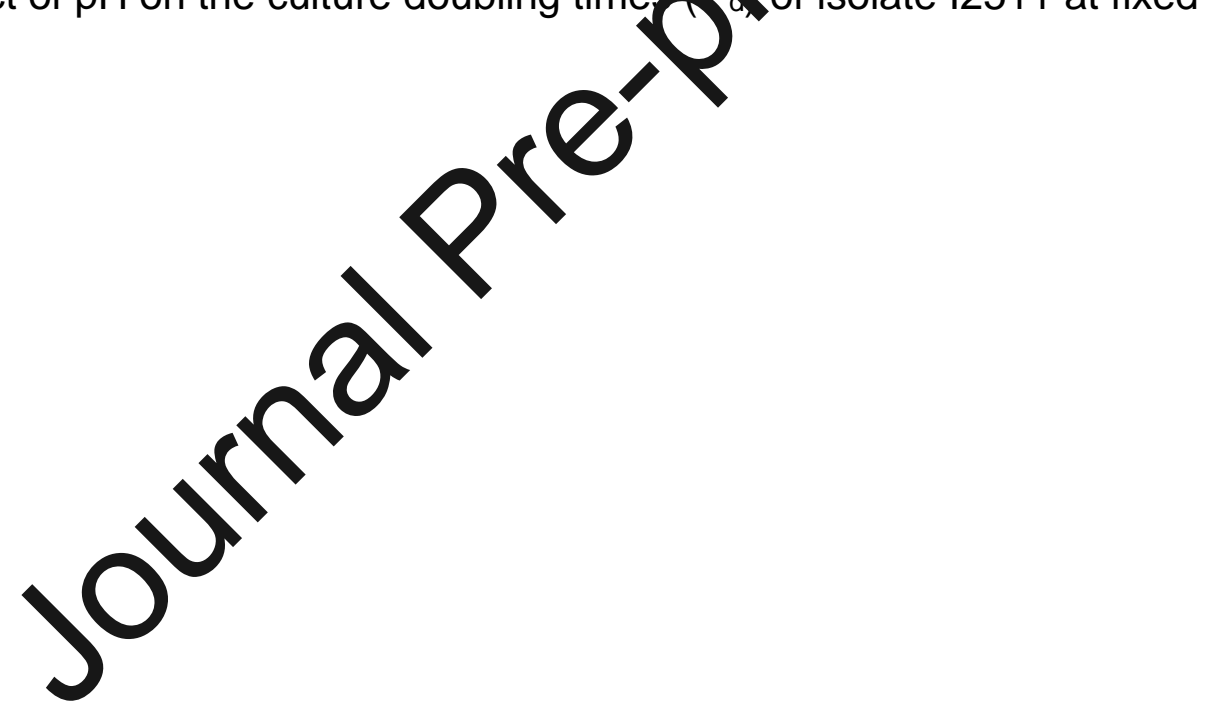

temperature $\left(30^{\circ} \mathrm{C}\right)$. 


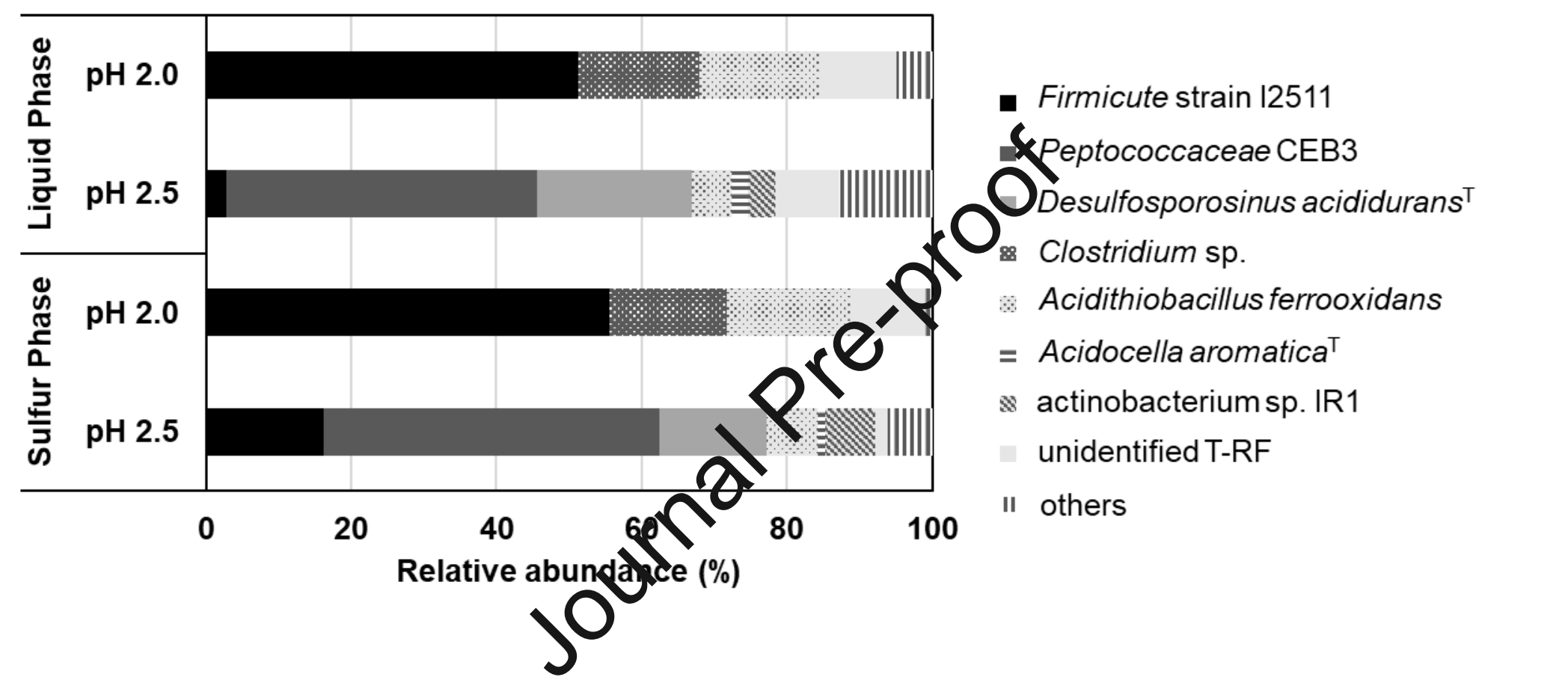

Figure 6. T-RFLP profiles of bacterial 16S rRNA genes amplified from DNA extracts and digested with the restriction enzyme Haelll during experiments operating the HSB at low $\mathrm{pH}$ in continuous flow mode. Sulfur phase correspond to DNA extracted from sulfurattached bacterial communities. Liquid phase correspond to DNA extracted from planktonic cells. 